DOI 10.1590/S0104-64972015002326

\title{
Conquering new territories in the "new world": the alien shrimp Athanas dimorphus Ortmann, 1894 (Decapoda: Alpheidae) on the coast of Pernambuco, northeastern Brazil
}

Alexandre Oliveira Almeida, Ana Carla Costa-Souza, Guidomar Oliveira Soledade and Patricia Souza Santos

Universidade Federal de Pernambuco, Centro de Ciências Biológicas, Departamento de Zoologia. Avenida Prof. Moraes Rêgo, 1235, Cidade Universitária. 50670-901 Recife, Pernambuco, Brazil. E-mail: (AOA) almeidaao@uol.com.br

\begin{abstract}
The occurrence of the alien alpheid shrimp Athanas dimorphus Ortmann, 1894 is reported for the first time for the state of Pernambuco, northeastern Brazil, based on two ovigerous females collected at Praia do Paraíso, near the Suape Harbor (08 21'29.9'S 34⒌'00.9'W). The species, native from the Indo-West Pacific region, was previously reported from two other Brazilian states (Ceará and São Paulo), also occurring in localities with nearby harbors. The presence of ovigerous females suggests that the species was successfully introduced into the area. The main possible introduction vectors for $A$. dimorphus in Pernambuco and the dispersal potential of the species along the Brazilian coast are discussed.
\end{abstract}

Key words: Crustacea, Caridea, bioinvasion, exotic species, new record.

\section{INTRODUCTION}

Twenty-four species of decapod crustaceans have been introduced in Brazil, most of them brachyuran crabs with 12 species recorded (see Tavares and Mendonça Jr., 2004; Maciel et al., 2011; Tavares, 2011; Pachelle et al., 2011; Almeida et al., 2012; Sant'Anna et al., 2012; Soledade et al. 2013). The five non-indigenous caridean shrimps recorded in Brazilian waters are native from two different regions: the Indo-West Pacific (Macrobrachium rosenbergii (De Man, 1879), Macrobrachium equidens (Dana, 1852), Athanas dimorphus Ortmann, 1894, and Lysmata vittata (Stimpson, 1860)) and the eastern Atlantic (Athanas nitescens (Leach, 1813 [in Leach, 1813-1814])).

The small alpheid shrimp $A$. dimorphus was first described from Upanga Reef (Dar-es-Salaam, Tanzania), and has been recorded from several localities in the Indo-West Pacific, including East Africa, Red Sea, Thailand, Hong Kong, Philippines, Japan, Australia (Western Australia,
Northern Territory, and Eastern Australia), and New Caledonia (Banner and Banner, 1973; Chace Jr., 1988). In the western Atlantic, this species was first reported from two localities along the coast of Ceará, northeastern Brazil, and was later reported from Ubatuba, São Paulo, southeastern Brazil (Pachelle et al., 2011; Almeida et al., 2012). In addition, Almeida et al. (2012) suggest that the recent finding of $A$. dimorphus at mutually distant sites of the Brazilian coast (Ceará and São Paulo) indicates that the species might also has been introduced in other Brazilian localities.

The objective of the present study is to report for the first time the occurrence of $A$. dimorphus in the state of Pernambuco, northeastern Brazil, expanding the known distribution range of the species in the Brazilian coast. This study also addresses possible introduction vectors for A. dimorphus in Pernambuco and the dispersal potential of the species along the Brazilian coast. 


\section{Material ANd Methods}

The shrimps were collected manually under rocks in the intertidal zone during a recent survey carried out at Praia do Paraíso (08 21'29.9”S $\left.34^{\circ} 57^{\prime} 00.9^{\prime \prime} \mathrm{W}\right)$, in Suape Bay, near Suape Harbor. The material was anesthetized on ice and preserved in $70 \%$ ethanol. The specimens were identified using descriptions and illustrations provided by Pachelle et al. (2011) and Almeida et al. (2012). Carapace length (CL, in $\mathrm{mm}$ ) was measured along the dorsal mid-line from the tip of the rostrum to the posterior margin of the carapace. The material is deposited in the Crustacean Collection of the Museu de Oceanografia da Universidade Federal de Pernambuco, Recife, Brazil (MOUFPE).

\section{Systematics}

Family Alpheidae Rafinesque, 1815
Athanas dimorphus Ortmann, 1894 (Fig. 1)
Material examined. 2 ovigerous females (CL 4.8 and $5.7 \mathrm{~mm}$ ), MOUFPE 15532, Brazil, Pernambuco, Cabo de Santo Agostinho, Suape Bay, Praia do Paraíso, under rocks, colls. G.O. Soledade, P.S. Santos, M.V. Oliveira, R.J.C. Paiva and E.G. Silva, 16.vi.2015.

Remarks. Our material agrees very well with the morphological description and illustrations provided by Pachelle et al. (2011) and Almeida et al. (2012). However, some variations were observed in the chelae of the first pereiopods as well as in the rostrum length. The chelae fingers are slightly longer than $1 / 2$ palm length and $1 / 2$ palm length in the smaller (CL $4.8 \mathrm{~mm}$ ) and larger (CL 5.7 $\mathrm{mm}$ ) female, respectively (see Fig. 1B, F). The rostrum length reaches half-length of the third segment of the antennular peduncle and slightly overreaches half-length of the second antennular peduncle in the smaller (see Fig. 1A) and larger

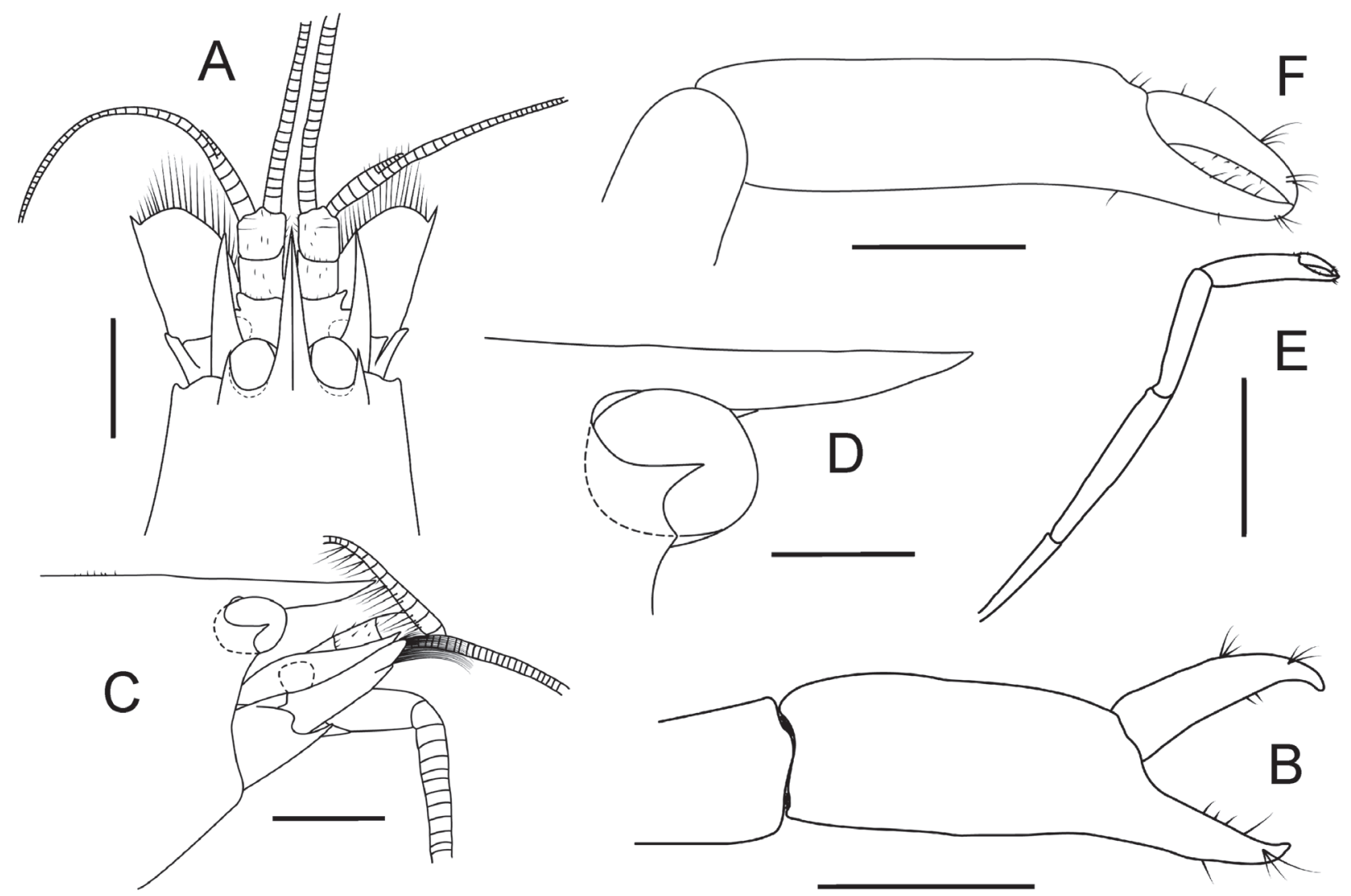

Figure 1. Athanas dimorphus Ortmann, 1894: (A, B) ovigerous female, CL $4.8 \mathrm{~mm}$, and (C-F) ovigerous female, CL $5.7 \mathrm{~mm}$, from Praia do Paraíso, Cabo de Santo Agostinho, Pernambuco, Brazil (MOUFPE 15532). (A) anterior margin of carapace and cephalic appendages, dorsal view; (B) left first chela, mesial view; (C) anterior margin of carapace and cephalic appendages, lateral view; (D) detail of anterior margin of carapace, lateral view; (E) left first cheliped, mesial view; (F) same, chela, mesial view. Scale bars : A, C : 1 mm; B, D, F : 0.5 $\mathrm{mm}$; $\mathrm{E}: 2 \mathrm{~mm}$. 
female, respectively. Such differences are most probably size-related.

Ballast water discharge containing larvae and adult transportation in hull fissures or among hull biofouling have been suggested as potential vectors of the introduction of $A$. dimorphus in Brazil (see Pachelle et al., 2011; Almeida et al., 2012). In fact, the collection sites of the species in Ceará and São Paulo are situated close to shipping and oil terminals (see Pachelle et al., 2011; Almeida et al., 2012). Two large harbors, Recife and Suape, are located on the coast of Pernambuco. Our material was collected very close to the latter harbor (Fig. 2), which is a potential site for introductions in Pernambuco. The Suape Harbor has an area of 13,500 hectares and is connected to more than 160 harbors in all continents, being currently the main harbor in Pernambuco and one of the five most important harbors in Brazil (Portos do Brasil, 2015). This scenario supports the idea that $A$. dimorphus might have been introduced in Pernambuco by means of ballast water, considering that some of the areas where the shrimp naturally occurs (e.g., United Arab Emirates, India and southern China) coincide with the main shipping routes of Suape (Portogente, 2005). On the other hand, the species might also have been introduced in Pernambuco via intracoastal traffic (see Tavares and Mendonça Jr., 1996; Tavares and Amoroux, 2003), from areas previously colonized by the species in Brazil, such as São Paulo (first collection in 2007) and Ceará (first collections in 2011) or another area of presently unreported occurrence.

Analyzing the current known distribution of $A$. dimorphus on the Brazilian coast (see Fig. 3) and the presence of ovigerous females in all the already registered locations, it is evident that this species has successfully established populations in several

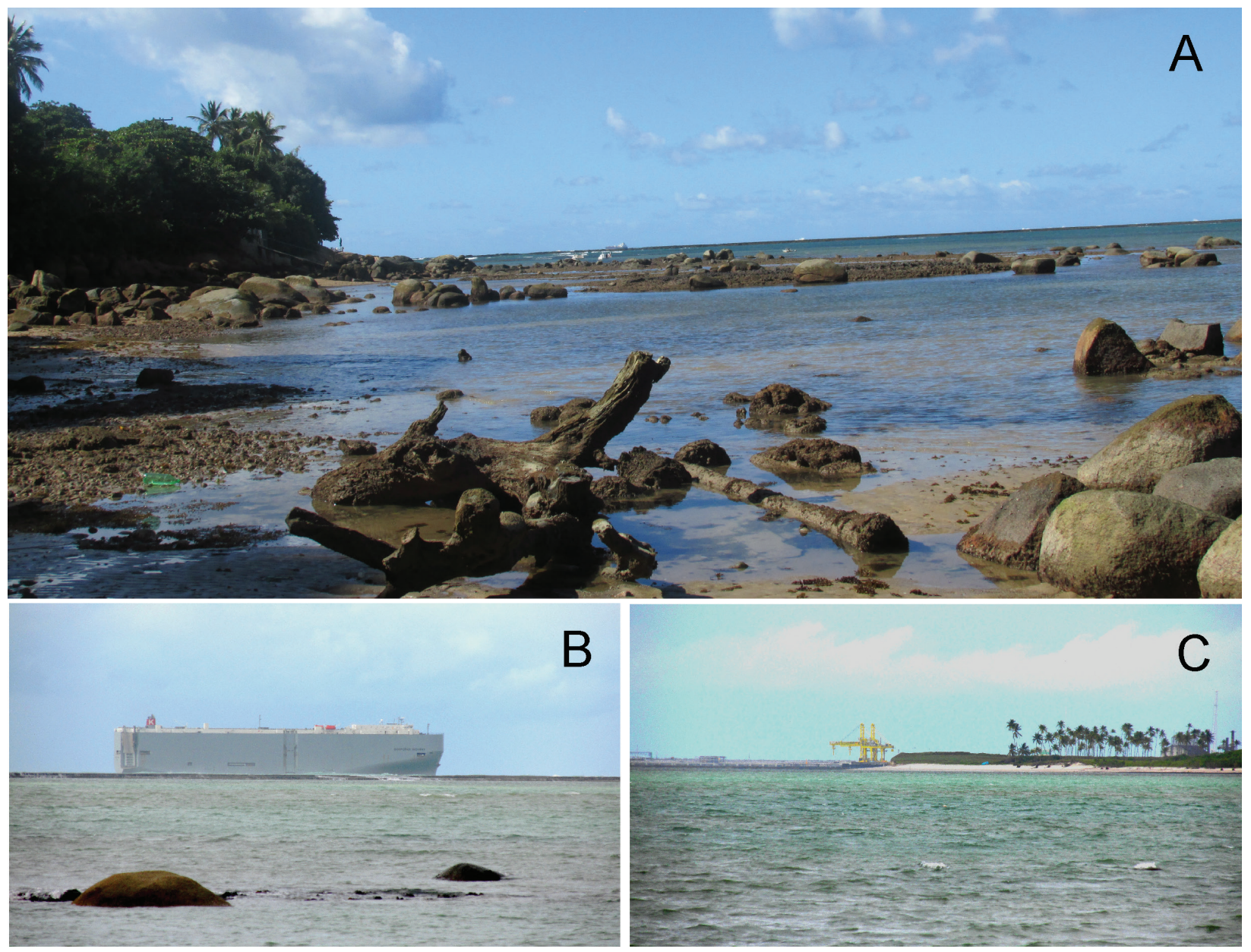

Figure 2. Photographs from Praia do Paraíso and the Suape Harbor area, Cabo de Santo Agostinho, Pernambuco, Brazil. (A) collecting site of the alien shrimp Athanas dimorphus Ortmann, 1894 at Praia do Paraíso; (B) ship traffic near the harbor entrance; (C) Suape Harbor. Photographs by Renata Lima da Silva. 


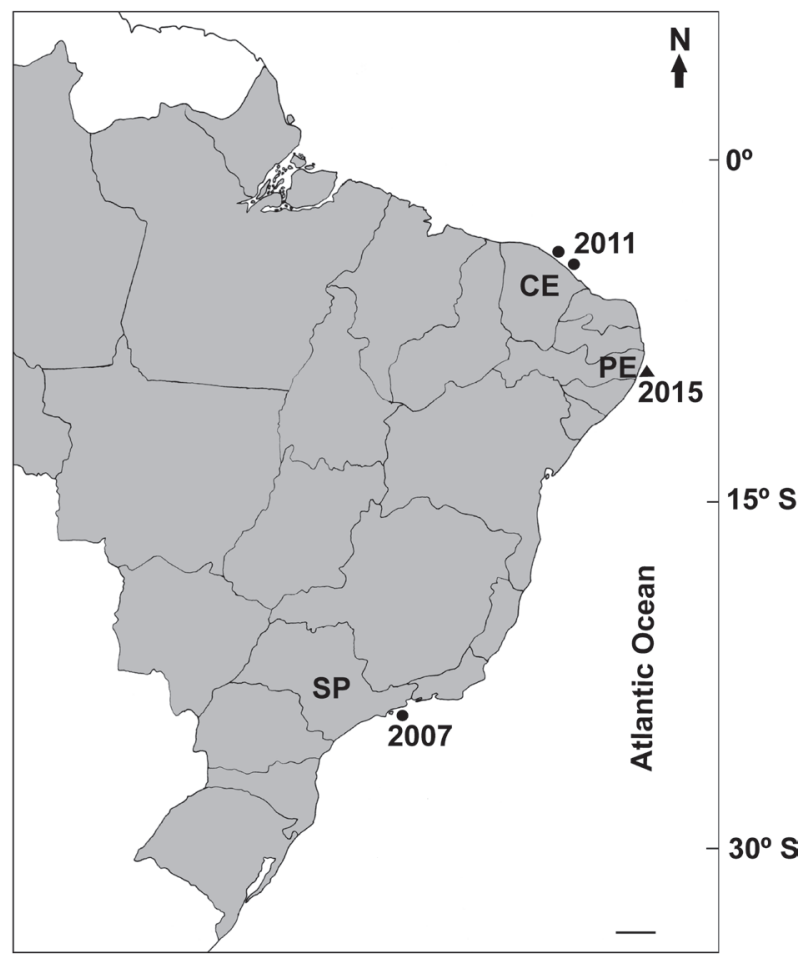

Figure 3. Distribution of the alien shrimp Athanas dimorphus Ortmann, 1894 on the Brazilian coast. Dates provided correspond to collection dates. Scale $=185 \mathrm{~km}$. $(\bullet)$ previous records; $(\boldsymbol{\Delta})$ new record.

areas of the country. The dispersal of the species in Brazil might follow the same pattern observed in another Indo-West Pacific decapod, the swimming crab Charybdis hellerii (A. Milne-Edwards, 1867), now widely distributed along the Brazilian coast and other parts of the western Atlantic (Tavares, 2011).

The two harbors from Pernambuco (Recife and Suape) may act as dispersal points for larvae to other areas in the country through ballast water or even adults colonizing fouling and/or crevices on ship hulls. Moreover, $A$. dimorphus may invade new areas by larval dispersal, especially areas to the north and northwest of Pernambuco, through the North Brazilian Current, which is a branch of the South Equatorial current originating near $10^{\circ} \mathrm{S}$ (Stramma et al., 1990).

Exotic species may cause several ecological and economic consequences. Athanas dimorphus and Athanas nitescens (the latter so far only reported from São Paulo in the western Atlantic) may compete with native alpheids such as Synalpheus spp., Automate spp. and Salmoneus spp.; however, their impact on indigenous fauna and habitats is expected to be low due to their biological and ecological characteristics (see Pachelle et al., 2011; Almeida et al., 2012). Additional sampling and reports aiming such invasive species in other areas in Brazil and the western Atlantic are desirable for a better understanding of the dispersal patterns and possible ecological impacts caused by this species.

\section{ACKNOWLEDGEMENTS}

The authors are indebted to the Fundação de Amparo à Ciência e Tecnologia de Pernambuco (FACEPE) for finnancing the Project "Sistemática de camarôes da família Alpheidae (Crustacea: Decapoda: Caridea) com ênfase no reconhecimento de espécies crípticas (processo APQ-0572-2.04/15)". The authors also thank Ricardo José de Carvalho Paiva, Elkênita Guedes Silva and Mário Vitor Oliveira for helping during the collections; Renata Lima da Silva for providing the photographs used in Figure 2; and Dr. Jesser Fidelis de Souza-Filho (Departamento de Oceanografia, Universidade Federal de Pernambuco) for his laboratorial support. Paulo Pachelle and an anonymous reviewer provided comments and suggestions that improved the manuscript.

\section{REFERENCES}

Almeida, A.O; Simóes, S.M.; Costa, R.C. and Mantelatto, F.L. 2012. Alien shrimps in evidence: new records of the genus Athanas Leach, 1814 on the coast of Sáo Paulo, southern Brazil (Caridea: Alpheidae). Helgoland Marine Research, 66(4): 557-565.

Banner, D.M. and Banner, A.H. 1973. The alpheid shrimp of Australia. Part I. The lower genera. Records of the Australian Museum, 28(15): 291-382.

Chace Jr., F.A. 1988. The Caridean Shrimps (Crustacea: Decapoda) of the Albatross Philippine Expedition, 19071910, Part 5: Family Alpheidae. Smithsonian Contributions to Zoology, 466: 1-99.

Dana, J.D. 1852. Conspectus Crustaceorum \&c. Conspectus of the Crustacea of the Exploring Expedition under Capt. C. Wilkes, U.S.N. Macroura. Proceedings of the Academy of Natural Sciences of Philadelphia, 1852: 10-29.

Leach, W.E. 1813-1814. Crustaceology. p. 383-437. In: D. Brewsler (ed) The Edinburgh Encyclopaedia, Vol. 7.

Maciel, C.R.; Quadros, M.L.A.; Abrunhosa, F.A.; Peixoto, S.N.B.; Schneider, H. and Sampaio, M.I.C. 2011. Occurrence of the Indo-Pacific freshwater prawn Macrobrachium equidens Dana 1852 (Decapoda, Palaemonidae) on the coast of Brazilian Amazonia, with notes on its reproductive biology. Anais da Academia Brasileira de Ciências, 83(2): 533-544. 
Man, J.G. de 1879. On some species of the genus Palaemon Fabr. with descriptions of two new forms. Notes from the Leyden Museum, 41: 165-184.

Milne-Edwards, A. 1867. Descriptions de quelques espéces nouvelles de Crustacés Brachyures. Annales de la Société entomologique de France, 4e série, 7: 263-288.

Ortmann, A. 1894. Zoologische Forshungreisen in Australien und dem Malayischen Archipel mit Unterstützung des Herrn Dr. Paul von Ritter ausgeführt in den Jahren 1891-1893. Crustaceen. Denkschriften der MedizinischNaturwissenschaftlich en Gesellschaft zu Jena, 8: 3-80, Pls. 1-3.

Pachelle, P.P.G.; Mendes, C.B. and Anker, A. 2011. The IndoWest Pacific alpheid shrimp Athanas dimorphus Ortmann, 1894: first record for Brazil and the Western Atlantic. Nauplius, 19(1): 89-96.

Portogente, 2015. Available at: https://portogente.com. $\mathrm{br} /$ noticias/portos-do-brasil/suape/suape-lideramovimentacao-entre-portos-do-norte-nordeste-86963. Accessed on 11 August 2015.

Portos do Brasil, 2015. Available at: http://www. portosdobrasil.gov.br/home-1/noticias/portos-brasileirosregistram-aumento-de-volume-de-cargas-no-quadrimestre. Accessed on 11 August 2015.

Rafinesque, C.S. 1815. Analyse de la natures ou tableau de Íunivers et dês corps organizes. Palermo, L'Imprimerie de Jean Barravecchia, 1-224.

Sant'Anna, B.S.; Watanabe, T.T.; Turra, A. and Zara, F.J. 2012. First record of the non-indigenous portunid crab Charybdis variegata from the western Atlantic coast. Biolnvasions Records, 1(1): 11-16.

Soledade, G.O.; Baeza, J.A.; Boehs, G.; Simóes, S.M.; Santos, P.S.; Costa, R.C. and Almeida, A.O. 2013. A precautionary tale when describing species in a world of invaders: morphology, coloration and genetics demonstrate that Lysmata rauli is not a new species endemic to Brazil but a Junior synonym of the Indo-Pacific L. vitatta. Journal of Crustacean Biology, 33(1): 66-77.

Stimpson, W. 1860. Prodromus descriptionis animalium evertebratorum, quae in Expeditione ad Oceanum Pacificum Septentrionalem, a Republic Federata missa, Cadwaladore Ringgold et Johanne Rodgers Ducibus, observavit et descripsit. Pars VIII, Crustacea Macrura. Proceedings of the Academy of Natural Sciences of Philadelphia, 1860: 22-47. [pages 91-116 on separate]

Stramma, L.; Ikeda, Y. and Peterson, R.G. 1990. Geostrophic transport in the Brazil Current region north of $20^{\circ} \mathrm{S}$. Deep-Sea Research, 37(12): 1875-1886.

Tavares, M. 2011. Alien decapod crustaceans in the Southwestern Atlantic Ocean. p. 251-268. In: B.S. Galil; P.F. Clark and J.T. Carlton (eds), In the Wrong Place Alien Marine Crustaceans: Distribution, Biology and Impacts. Invading Nature - Springer Series in Invasion Ecology, Vol. 6. Dordrecht, Springer.

Tavares, M. and Amouroux, J.M. 2003. First record of the non-indigenous crab, Charybdis hellerii (A. Milne-Edwards, 1867) from French Guyana (Decapoda, Brachyura, Portunidae). Crustaceana, 76(5): 625-630.

Tavares, M.D. and Mendonça Jr., J.B. 1996. Charybdis hellerii (A. Milne Edwards, 1867) (Brachyura: Portunidae), eight nonindigenous marine decapods recorded from Brazil. Crustacean Research, 25: 151-157.

Tavares, M.D. and Mendonça Jr., J.B. 2004. Introdução de Crustáceos Decápodes Exóticos no Brasil: Uma Roleta Ecológica. p. 59-76. In: J. Silva and R. Souza (Orgs) Água de Lastro e Bioinvasão. Rio de Janeiro, Interciência. 
